\title{
Abortion policies around the world and in Turkey and its reflection on women's health
}

\begin{abstract}
Approximately 46 million women experience abortion all around the world every year and about 22 million of those being done in precarious conditions. $13 \%$ of the maternal mortality is associated with unsafe abortion practices. Every year near 5 million women are hospitalized because of unsafe abortion. The cost for treatment of the complications related to unsafe abortion is estimated to be 680 million dollars annually. Two third of the maternal mortality occurs in African countries and when these rates are thoroughly analysed it can be seen that African and Asian countries' law limit abortion practices. In the developed countries where discretionary abortion is not legally limited, maternal mortality rates stay under $1 \%$, on the other hand, abortion limited/banned countries show the highest rates.
\end{abstract}

Key words: Discretionary/Voluntary Abortion; Policies; Woman Health.

\section{Introduction}

208 million pregnancies occur all around the world annually and $59 \%$ of those are planned and wanted, while the remaining $41 \%$ (85 million) are unwanted (WHO, 2012). The first option considered for those unwanted pregnancies is abortion; discretionary termination of pregnancy. WHO (World Health Organization) defined abortion as the termination of the pregnancy before fetus gains ability to survive out of uterus. Abortion is considered under two categories; discretionary and spontaneous (WHO, 2012). Spontaneous abortions and stillbirth occur without woman's will while discretionary abortion is made by consent. Discretionary abortion is an important matter because of destructive effects on woman's health, decreasing the chance of future pregnancies and increasing perinatal mortality (TNSA, 2013). This article aims to examine and discuss world's and Turkey's abortion policies and the impact on woman health as well

\footnotetext{
1 Assistant Professor, Ph.D., Istanbul Aydin University, Faculty of Health Science, Nursing Department, Istanbul, Turkey, yildaarzum@hotmail.com

2 Assistant Professor, Ph.D., Istanbul Aydin University, Faculty of Health Science, Health Management Department, Istanbul, Turkey, gokhanaba@aydin.edu.tr

${ }^{3}$ Ph.D., Kocaeli The Association of Public Hospitals, Kocaeli, Turkey, sirinozkan16@,hotmail.com.tr

${ }^{4}$ Assistant Professor, Ph.D., Istanbul Aydin University, Faculty of Health Science, Nursing Department, Istanbul, Turkey, vilmazguzel47@gmail.com
} 
Aba, Y. A., Aba, G., Özkan, S.., \& Güzel, Y. (2016). Abortion policies around the world and in Turkey and its reflection on women's health. International Journal of Human Sciences, 13(1), 1651-1665. doi:10.14687/ijhs.v13i1.3580

\section{Abortion Policies Around the World}

Abortion laws of countries are generally affected by the international goals although they are shaped by a country's cultural background, history and its government's ideology. Legal abortion discussions are based on woman rights, fetus rights, religious and legal principles. Legal abortion frame is always in the best interest of feminists as it is naturally about women's selfautonomy on their body and fertility. The legal limitation on abortion is perceived by many as a threat to hardly earned women rights (Levels, Sluiter \& Need, 2014).

Laws about abortion started to be shaped in $19^{\text {th }}$ century around the globe. In 1896, Pope Pius IX period, the matter to involve with abortion was brought up to public's attention and any abortion for any reason was banned by law. These laws still precipitate abortion limitations in developing countries (Jones \& Lopez, 2013). In between 1950 and 1985, almost all first world countries constitute their own abortion laws for human rights and safety. The laws limiting abortion, generally continue to be effective in the developing countries because of the colonization implications (Rahman, Katzive \& Henshaw, 1998). $25 \%$ of the world's population lives in those countries where abortion is banned by law in Asia, Africa and Latin America.

In the report published in 2009 by European Union (UN) Economical and Social Council Population Commission, the information indicated included: countries' abortion laws, abortion rates, total birth numbers, maternal mortality rates, government's methods for supporting family planning and prevalence of different family planning methods. The report, in fact, included the countries where abortion was legal and in which circumstances abortion would be allowed.(Levels, Sluiter \& Need, 2014; UN, 2014a). The countries' abortion laws are categorized as below:

1. The laws does not allow abortion in any circumstances

2. The laws abortion is only allowed to save woman's life

3. Abortion for reasons to protect woman's physical wellbeing is allowed

4. Abortion for reasons to protect woman's psychological wellbeing is allowed

5. Abortion is allowed for only in the case of incest or rape

6. Abortion is allowed for only fetus abnormalities

7. Abortion related to social or economic reasons is allowed

8. Discretionary abortion laws

Figure 1 shows the countries or regents with their abortion laws and given color code related limitation of abortion. Red colored regents show the countries which totally banned abortion or only allowed to save women's life, orange places show the countries in which abortion is legally complicated or obstructed, yellow describes places where abortion for economic or social reasons is allowed and lastly green parts indicate the places where abortion is allowed totally. 
Aba, Y. A., Aba, G., Özkan, S.., \& Güzel, Y. (2016). Abortion policies around the world and in Turkey and its reflection on women's health. International Journal of Human Sciences, 13(1), 1651-1665. doi:10.14687/ijhs.v13i1.3580

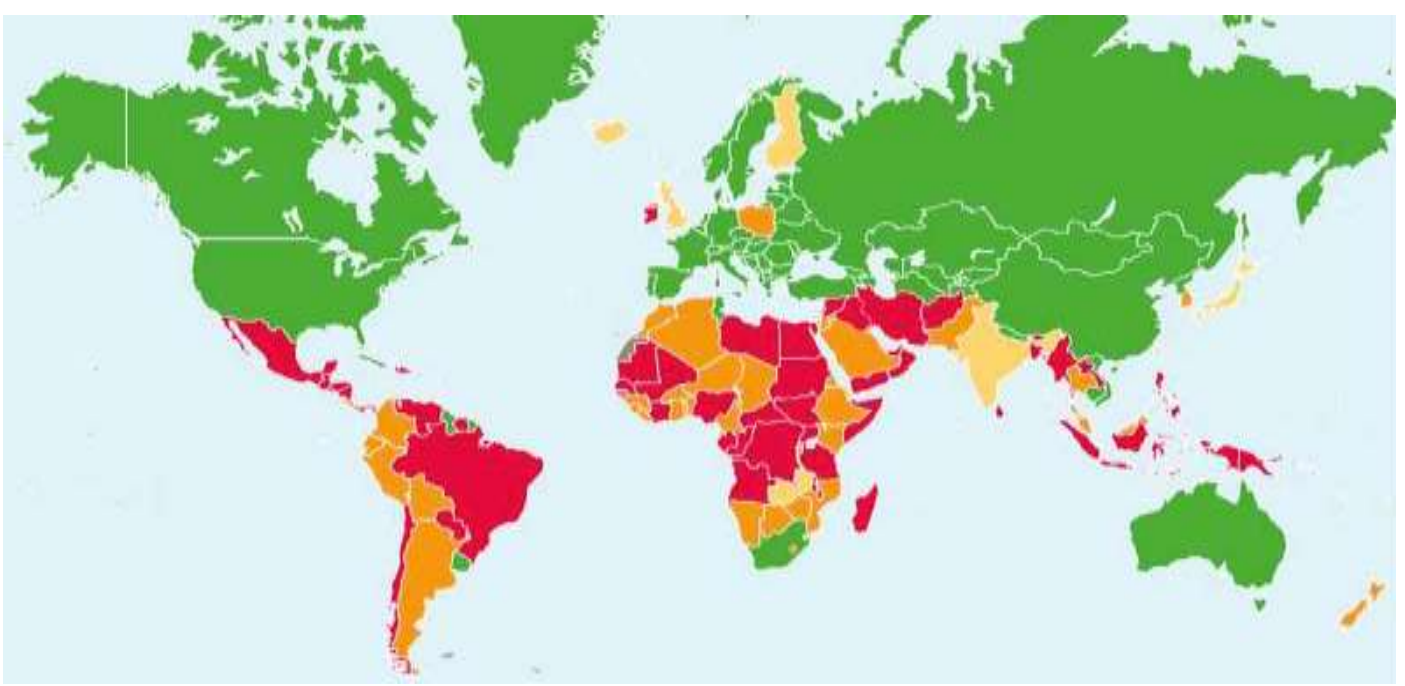

Figure 1. The World Abortion Laws

In recent years, many countries shifted their legal base for abortion. In 2013, $97 \%$ of the countries improved their abortion laws to save women's life. By the same year, approximately two third of the countries allowed abortion only when mother's physical and psychological health was at risk and half of the countries only allowed abortion when the pregnancy was after an incest relation or rape. Only the third of the countries allowed abortion for economic, social or discretionary reasons. Chile, Dominican Republic, El Salvador, Vatican, Malta and Nicaragua do not allow abortion in any circumstance (UN, 2014a). Abortion policies are an issue still discussed even in the countries that allow abortion. Today, still some political or religious groups in Hungary, Poland, Germany, Spain, Sweden and US continue to argue that abortion should be banned or limited.

When regional distribution considered the strictest abortion laws is seen in Oceania than Africa, Latin America and Caribbean. Only the 6\% of Oceania and African countries and only the $12 \%$ of the Latin American and Caribbean countries allow discretionary abortion. 18 countries in African region, 12 countries in Asian continent, 8 countries from Latin American and Caribbean region, 8 countries from Oceania allow abortion only when a woman's life is at risk. On the contrary, in 2013, European and North American countries made the most liberal abortion laws in the world and $73 \%$ of those countries allowed discretionary abortion by law (UN, 2014a).

By 2013, only the $36 \%$ of the countries allowed abortion for social and economic reasons and those countries comprised of $61 \%$ of the world's population. This discrepancy occurred because highly populated countries like China and India allowed abortion on the legal bases (UN, 2014a).

From 1996 to 2013, more countries agreed on allowing abortion in order to save woman's life and the percentage of those who allowed it reached to $97 \%$ of all countries. In this period, also the number of the countries that allowed abortion for protecting woman's health increased from $63 \%$ to $67 \%$ of all while the percentage of countries allowing abortion for protecting woman's psychological wellbeing also increased from $52 \%$ to 64 . Similarly, the rate of allowing the termination of pregnancies after rape or incest increased from $43 \%$ to 52 and the rate of legal termination dur to fetal abnormality raised to $52 \%$ from $41 \%$ (UN, 2014a).

From 1996 to 2013, in 56 countries around the world (20 African, 12 Asian, 12 Latin American/Caribbean, 8 European and 4 Oceanien) the laws about abortion practices are expanded. On the other hand, 8 countries restricted their abortion laws (3 Latin American/Caribbean, 2 African, 2 Asian and 1 Oceanian) (UN, 2014a, UN, 2014b). 

on women's health. International Journal of Human Sciences, 13(1), 1651-1665. doi:10.14687/ijhs.v13i1.3580

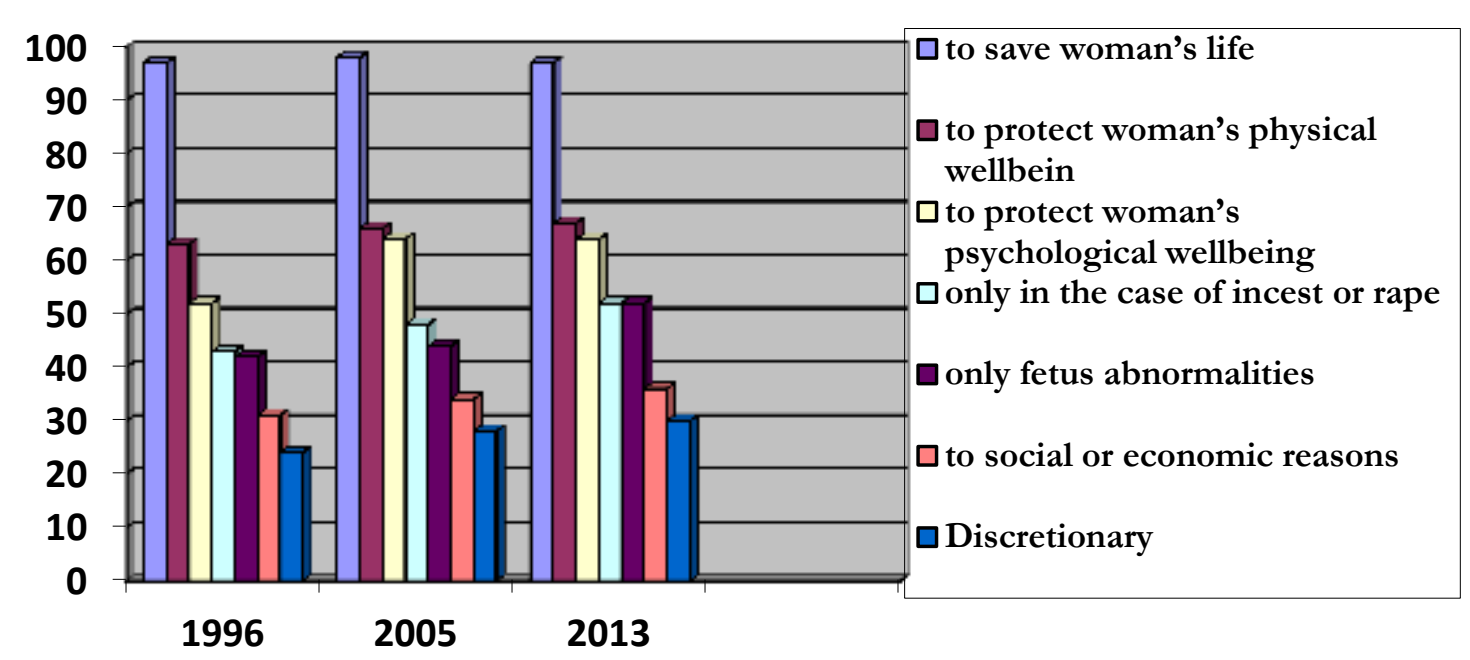

Graph 1. Changes in legal grounds for abortion, 1996-2013

The graph above shows the countries allow abortion are compared for their ground. Only the one third of all countries allow abortion for socio-economic reasons or personal choice (UN, 2014b).

In $2013,82 \%$ of developed countries allow abortion for economic and social reasons, $71 \%$ allowed discretionary abortion. Additionally, $20 \%$ of the developing countries allowed for economic/social reasons while only 16\% allow discretionary abortion (UN, 2014b).

Un the recent past 5 years, 87 out of 145 countries took preventive measures to provide safe, according to the 21012 data. In 2013, the number of countries which applies prenatal policies increased from 14\% to 27\%. Moreover, between 1996 and 2013, the number of governments which follow policies towards preventing adolescent pregnancy was climbed up to $90 \%$ by $30 \%$. The countries with strict abortion laws present 3 times bigger fertility and adolescent pregnancy rates compare to the others. Consequently, abortion policies of countries affect women's and children's health directly. When abortion is banned, that countries' maternal mortality rate rise significantly. The countries with strict abortion laws show 26.7 unsafe abortion in 1000 while same rate for more liberal countries is 6.1. in addition, maternal mortality 223 by every 100.000 live birth compare to the countries which 77 (UN, 2014a). 
Aba, Y. A., Aba, G., Özkan, S.., \& Güzel, Y. (2016). Abortion policies around the world and in Turkey and its reflection on women's health. International Journal of Human Sciences, 13(1), 1651-1665. doi:10.14687/ijhs.v13i1.3580

Table 1: The countries liberal and restrict their abortion laws between 1996-2013

\begin{tabular}{|c|c|c|}
\hline Legal base to allow abortion & Liberalized Countries & Strict Countries \\
\hline Saving woman's life & Andorra & Dominican Republic, Nicaragua \\
\hline $\begin{array}{l}\text { Protecting woman's physical } \\
\text { health }\end{array}$ & $\begin{array}{l}\text { Benin, Chad, Columbia, Ecuador } \\
\text { Guinea, Kenya, Lao, Mexico, } \\
\text { Mozambique, Nepal, Niger, } \\
\text { Nigeria, Swaziland, Togo, United } \\
\text { Arab Emirates }\end{array}$ & Congo, Iraq, Papua New Guinea \\
\hline $\begin{array}{l}\text { Protecting woman's psychological } \\
\text { health }\end{array}$ & $\begin{array}{l}\text { Benin, Bhutan, Bolivia, Burkina } \\
\text { Faso, Burundi, Kameron, } \\
\text { Colombia, Comoro, Costa Rica, } \\
\text { Ecuador, Ecuador Guinea, } \\
\text { Ethiopia, Kenya, Mexico, } \\
\text { Morocco, Mozambique, Nepal, } \\
\text { Niger, Nigeria, Peru, Poland, } \\
\text { Qatar, Ruanda, Saudi Arabia, } \\
\text { Swaziland, Thailand, UAE, } \\
\text { Uruguay, Vanuatu }\end{array}$ & Iraq, Papua New Guinea, Japan \\
\hline Rape or incest relation & $\begin{array}{l}\text { Argentina, Bahamas, Bahrain, } \\
\text { Benin, Bhutan, Burkina Faso, } \\
\text { Colombia, Cook Islands, Eritrea, } \\
\text { Ethiopia, Fiji, Indonesia, Mali, } \\
\text { Monaco, Nepal, Saint Kitts and } \\
\text { Nevis, Saint Lucia, Swaziland, } \\
\text { Switzerland, Swaziland, Togo, } \\
\text { Uganda, Uruguay }\end{array}$ & Algeria, Belize, Ecuador, Iraq \\
\hline Fetus abnormalities & $\begin{array}{l}\text { Bahamas, Benin, Burkina Faso, } \\
\text { Chad, Colombia, Eritrea, } \\
\text { Ethiopia, Fiji, Indonesia, Iran, } \\
\text { Jordan, Mexico, Monaco, Nepal, } \\
\text { Niger, Oman, Saint Lucia, } \\
\text { Swaziland, Switzerland, Togo, } \\
\text { Uganda, Uruguay }\end{array}$ & Iraq \\
\hline Economic or social reasons & $\begin{array}{l}\text { Bahrain, Fiji, Mexico, Nepal, } \\
\text { Portugal, Saint Vincent and } \\
\text { Grenadines, Spain, Switzerland, } \\
\text { Uruguay }\end{array}$ & - \\
\hline Discretionary abortion & $\begin{array}{l}\text { Australia, Bahrein, Belgium, Cabo } \\
\text { Verde, Italy, Mexico, Nepal, } \\
\text { Portugal, Spain, Switzerland, } \\
\text { Uruguay }\end{array}$ & - \\
\hline
\end{tabular}

United Nations. Department of Economic and Social Affairs, Population Division. Abortion Policies and Reproductive Health around the World, 2014.

Table 1 show the countries which have freed or restricted abortion policies between the years of 1996-2013. The weight of limiting abortion policies continue in developing countries. By 2013, only 48 of the developing 148 countries had allowed abortion under all circumstances. This ratio is 41 out of 49 for developed countries (UN, 2014b). 
Aba, Y. A., Aba, G., Özkan, S.., \& Güzel, Y. (2016). Abortion policies around the world and in Turkey and its reflection on women's health. International Journal of Human Sciences, 13(1), 1651-1665. doi:10.14687/ijhs.v13i1.3580

In countries where abortion is legally difficult or restricted, having an abortion in healthy circumstances becomes a privilege of the rich people; whereas women with poorer conditions are forced to have abortions in unsafe circumstances. The social and financial liabilities of abortions resulting in death or additional diseases stem from the healthcare system (WHO, 2012). In light of these, the prohibition of abortion results in healthcare inequalities.

The technological advancements and the increased awareness of women's rights during the second half of the 20th century have greatly changed the circumstances recently. Women and couples are highly autonomous about reproduction and fertility rates have decreased in Europe. For example, Dutch women have the lowest fertility rate around the world. In addition to this, some European countries still have old school procedures and outworn medical and social services practices in place. An example would be the mandatory "psychological counseling committee approval" women are supposed to get before getting an abortion. Although this practice was annulled in France a couple of years ago, some countries still continue to run it. For example, all doctors provide psychological counseling services prior to abortion in Holland and Austria. Although there is no regulation on the content of the counseling in question, it is more difficult to get an abortion in Germany (Fiala, 2005).

One of the outdated practices used in delaying abortion is "mandatory waiting time." According to this, pregnant women have to get a counseling service before getting an abortion and a "mandatory amount of time" has to pass between the counseling session and the abortion. The mandatory waiting times in European countries are shown in Table 2 (Fiala, 2005).

Table 2: Mandatory Waiting Times in Some European Countries

\begin{tabular}{|l|l|l|}
\hline Countries & Waiting times & Details \\
\hline Belgium & 6 days & Following the first counseling session. \\
\hline Germany & 3 days & $\begin{array}{l}\text { Following the approval of a certified counseling } \\
\text { center. }\end{array}$ \\
\hline France & 7 days & $\begin{array}{l}\text { After the first meeting with a specialist (doctor } / \\
\text { counselor / midwife / nurse), this duration may } \\
\text { shorten as the legal abortion time limit approaches. }\end{array}$ \\
\hline Holland & $\begin{array}{l}5 \text { days (44 days after the date of } \\
\text { last period) }\end{array}$ & $\begin{array}{l}5 \text { days after meeting with a specialist, this duration } \\
\text { may shorten as the legal abortion time limit } \\
\text { approaches. }\end{array}$ \\
\hline Italy & 7 days & $\begin{array}{l}7 \text { days after the first meeting with a certified } \\
\text { physician. }\end{array}$ \\
\hline Austria, Denmark, Finland, Norway, Spain, Sweden, Switzerland do not have mandatory waiting periods. \\
\hline
\end{tabular}

While these limitations vary from country to country, abortion is legally permitted in many European countries. Restriction on abortion is usually seen in countries with strong Catholic faith. In many countries of the European Union, abortion can be performed on demand during the first trimester. The abortion laws of the European countries has been shown in Table 2 (Abortion Clinics in Europe, 2015). Countries painted in green represent those with easy access to abortion, those painted in yellow represent partially countries with partially solid abortion policies and those painted in red represent countries where abortion is illegal. 


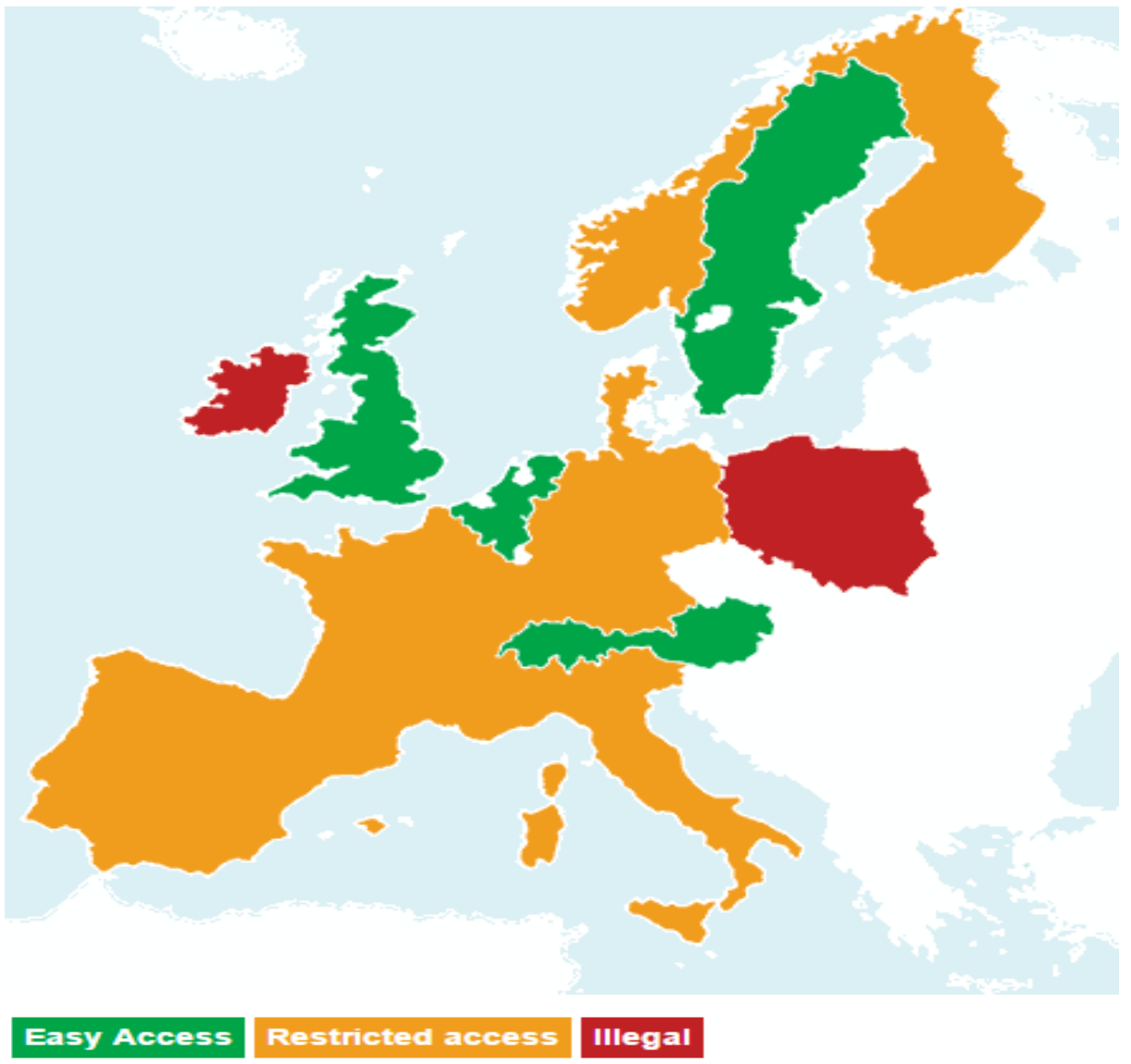

Figure 2. Abortion Laws in Europe , 2014 (Abortion Clinics in Europe, Legal situations in Europe, bttp:/ / wnww.abortion-clinics.eu/ 15.04.2015)

European Countries with easy access to abortion (Abortion Clinics in Europe, 2015):

- Austria: Abortion is legal until the end of the 12th week starting from the date of last menstrual period.

- Belgium: Abortion can be performed until the end of the 14 th week starting from the date of last menstrual period.

- England: Abortion is permitted until the 24th week. Abortion is legally permitted until the 24th week in cases where the pregnancy is at risk, termination occurs, the woman gets psychological damage or there is another child in the family.

- Holland: Abortion can be performed on request until the $13^{\text {th }}$ week.

- Norway: The legal limit is 12 weeks on request.

- Sweden: Abortion-on-request is legally permitted until the $18^{\text {th }}$ week and abortion due to strong reasons is permitted until the $22^{\text {nd }}$ week.

- Switzerland: The legal limit is 12 weeks on request.

\section{European countries where abortion is restricted:}

- Denmark: Abortion can be performed on request until the $12^{\text {th }}$ week; but only by a physician of public office and in a public hospital. 
Aba, Y. A., Aba, G., Özkan, S.., \& Güzel, Y. (2016). Abortion policies around the world and in Turkey and its reflection on women's health. International Journal of Human Sciences, 13(1), 1651-1665. doi:10.14687/ijhs.v13i1.3580

- Finland: It is permitted until the $12^{\text {th }}$ week, but must be justified by the woman's health being in danger, the baby having a genetic disease, the family having a serious issue, the woman being psychologically unstable, rape or other sexual crimes, the woman being under 17 or over 40, the woman having more than 4 kids or the existence of malformation.

- France: It is permitted until the $12^{\text {th }}$ week, but the woman must prove that this pregnancy will create a serious social problem for her. The woman must take recommendations from a physician and a social worker prior to having the abortion. If the woman still wants to get the abortion, she must report her decision in writing to her physician at the end of a mandatory decision period of 1 week.

- Germany: The woman must report a serious social and health issue in order to have the abortion until 12 weeks into the pregnancy.

- Italy: Abortion is permitted until the $90^{\text {th }}$ day, but the woman must report a serious health or social issue in order to justify it.

- Portugal: The woman must report a serious social or health issue in order to have the abortion within the permissible limit of 12 weeks.

- Spain: Abortion is performed until the $12^{\text {th }}$ week in rape cases.

\section{European countries where abortion is legally forbidden:}

- Andora: In the framework of general principles of criminal law, abortion can be performed only to save the life of the pregnant woman.

- North Ireland: Unlike other European countries, North Ireland is the only country where abortion is deemed a crime. Women who need to have abortions must go to England and other European countries to get it done.

- Republic of lreland: Abortion is illegal under all circumstances.

- Malta: Abortion is illegal under all circumstances. Those who perform and get an abortion are punished with imprisonment between 18 and 36 months.

- Poland: Abortion is allowed only in cases where pregnancy poses a serious health threat to the mother's life or the fetus.

- San Marino: This small European state continues to ban abortions.

Although liberalization of the abortion laws has been observed throughout the world during the recent years, restrictions and prohibition still continues in some countries. Malta is the only country in the EU which bans abortion. Religion is an important factor on the abortion laws. Malta has been warned by the European Parliament and UN to review their abortion policies and legalize abortion in order to make it legal, safe and available. However, despite all warnings from the regional and international organizations, Malta has refused to change their abortion policies (Bozkurt, 2013).

China has been applying "One Child" policy since 1979 due to economic reasons. According to this, each couple is allowed to have one child only. In rural areas, couples who have daughters as their first children are allowed to have a second child. Minority groups are allowed to have maximum 3 children. Families are obliged to pay legal penalties in accordance with their income if they disobey these rules. The legal limit for abortion is 6 months. These practices carried out in China and Malta show just how rigid the interventions of the states on the fertility of their citizens can be in order to hit their target populations (Bozkurt, 2013). 
Aba, Y. A., Aba, G., Özkan, S.., \& Güzel, Y. (2016). Abortion policies around the world and in Turkey and its reflection on women's health. International Journal of Human Sciences, 13(1), 1651-1665. doi:10.14687/ijhs.v13i1.3580

\section{Abortion Indicators around the World}

The abortion rate around the world have dropped from 35/1000 individuals to 29/1000 individuals for women between the ages of 15-44 from 1995 to 2003. This rate has stayed the same between the years of 2003 and 2008, and since 2008, 28/1000 is the observed rate (Sedgh, Singh, Henshaw \& Bankole, 2012; Shah, Åhman \& Ortayli, 2014).

In developed and developing countries, 8 million and 38 million abortions have been performed respectively in 2008. This uneven distribution largely reflects the population distribution. Generally around the world, the abortion rate has increased from $78 \%$ to $86 \%$ in developing countries between the years of 1995 and 2008. The number of women living in developing countries seems to have affected the increase in abortion rates in these countries (Sedgh, Singh, Henshaw \& Bankole, 2012).

About half of the abortions performed in the world are performed under unsafe circumstances. $56 \%$ of all unsafe abortions are performed in developing countries and $6 \%$ are performed in developed countries (Sedgh, Singh, Henshaw \& Bankole, 2012).

Europe is the region with the lowest abortion rate where abortion is legal and commonly used (Animaw \& Bogale, 2014). In countries with legal restrictions, the abortion rates are not seen to be low. For example, the abortion rates in Africa and Latin America, where abortion is legally restricted, are $0.29 \%$ and $0.32 \%$. In Western European countries where justified abortion is permitted, this rate goes down to $0.12 \%$ (Bozkurt, 2013). In Columbia and Uganda, 400.000 and 300.000 abortions are performed yearly on request. This number reaches 2 million in Indonesia (Darney, Simancas-Mendoza, Edelmana, Guerra-Palacioc, Tolosaa \& Rodriguez, 2014; Kauffman, 2015).

Almost $70 \%$ of women under 30 experience abortion in Latin America, whereas in developing countries, 14\% of all women under 20 have had an abortion (Darney, SimancasMendoza, Edelmana, Guerra-Palacioc, Tolosaa \& Rodriguez, 2014).

In Pakistan, abortion is permissible during the first trimester to save to life of the mother only. 890.000 abortions on request are thought to be performed yearly. These are usually reported to be performed under unsafe circumstances and by uneducated individuals (Shaikh, Abbassi, Rizwan \& Abbasi, 2010).

\section{Abortion Policies in Turkey}

The historical process regarding abortion is analyzed in three periods during the Republican Era: Probibition period between 1923-1965, transition era between 1965-1983 and liberalization era starting from 1983 (Kaleci, Mete, Ünsal \& Yıldırım, 2013). During the first years of the Republic, it was needed to increase fertility due to heavy loss of people during the First World War and Independence War, and the dependence of the economy on labor-intensive agricultural production. Beside the lack of labor force and the country's need of defense, high infant and children mortality rates have driven Turkey to follow a pronatalist population policy until the end of 1950s. Many laws that encourage population growth directly or indirectly have been adopted during this period. These included women who had five or more children receiving money prizes, tax reduction incentives, prohibition of the advertising, import and sale of pregnancy prevention methods (TNSA, 2013). Due to the sanctions of terminating a pregnancy on request, although being a common practice, there are no data on the miscarriages between 1927-1955. However, as the data of women who were referred to hospitals or private clinics after 1955s are examined, they are seen to have abortions or try to terminate their pregnancies with their own primitive methods; and maternal deaths due to willful miscarriages are seen to be very high (Tezcan, 2012). This pronatalist politics continued until 1960s, but was questioned beginning from the ends of 1950s. The demobilization of men under arms after World War II and the improvements in the healthcare 
Aba, Y. A., Aba, G., Özkan, S.., \& Güzel, Y. (2016). Abortion policies around the world and in Turkey and its reflection on women's health. International Journal of Human Sciences, 13(1), 1651-1665. doi:10.14687/ijhs.v13i1.3580

system have caused a decrease in infancy mortality rate, which has caused a rapid increase in the population together with an increase in fertility, which has resulted in a population increase to 24 million from 13 million between the years of 1923-1955 (Kubilay, 2012). The high increase in population in the 1950s has caused an increase in illegal abortions and employment issues have played an important role in the state's attitude against abortion, causing them to lean more towards the antinatalist policy (TNSA, 2013).

The responsibility of administering the new family planning policy has been given to the Ministry of Health with Family Planning Law no. 557, adopted on 10 April 1965. With this law, the import of modern pregnancy-preventing methods have been allowed, free service was provided in public health institutions and the education of couples on family planning was supported. Despite all of this, abortion was not liberalized and allowed only when the pregnancy posed a health threat on the mother or the baby (Nüfus Planlamas1 Hakkinda Kanun, 1965). After about twenty years of practice, the insufficiencies of these services were recognized and Family Planning Law no. 2827 was adopted on 27 May 1983. With this law, abortion was allowed until the $10^{\text {th }}$ week of pregnancy without the justification of a threat to the mother's health (Nüfus Planlamas1 Hakkinda Kanun, 1983). Abortion was then legalized and abortion service on request was provided until the $10^{\text {th }}$ week to every willing woman. Since this regulation, abortion has been performed in state hospitals at a symbolic cost and in private hospitals for those who can afford it (TNSA, 2013).

\section{Abortion Indicators in Turkey}

The most important sources of national information on abortion in Turkey are the population and health studies, which are performed by Hacettepe University Institute of Population Studies (HUNEE) every five years since 1968. The rate of miscarriage on request among women between the ages of 15 and 49 before the legalization of abortion were 0.76 in 1983 and 0.14 in 2013. According to the 2013 data of TNSA, 14\% of all married and fertile women in Turkey have had at least one abortion. 4.7 of 100 pregnancies resulted in miscarriage on request. $62 \%$ of miscarriage on demand is performed by the private sector. $63 \%$ and $24 \%$ of women between the ages of 15 and 49 have willful miscarriages during the first and second month of their pregnancies (TNSA, 2013).

Regional findings show that total miscarriage rates are highest in urban areas: 0.16 in the western areas and 0.20 in Istanbul. The total miscarriage rate does not differ according to education. However, total rate of miscarriage increases with household welfare. Total rate of miscarriage among women in households in the lowest level of welfare is 0.12 while this number increases to 0.19 among women in households with higher welfare levels (TNSA, 2013).

\section{The Effects of Abortion Policies on Women's Health}

Abortion is performed under safe circumstances in countries where it is legalized and under unsafe circumstances where it is prohibited. The regulations in the abortion law are of great importance in preventing the health issues of women who undergo unsafe abortions and women mortality (Jones \& Lopez, 2013). WHO defines "unsafe abortion" as a procedure for terminating an unwanted pregnancy either by persons lacking the necessary skills or in an environment lacking minimal medical standards. Despite its common use, it is the first definiton made by WHO in 1992 and it has some shortcomings. The education and skills of the person performing the abortion and safe abortion practices need to be more thoroughly defined (Ganatra et all., 2014).

Abortion performance is not standard. It depends on circumstances and is open to development in light of evidence-based WHO suggestions. In the definition of safe abortion, the right person to perform the abortion and appropriate medical standards are different for medical and surgical abortion and depends on how far along the pregnancy is. Whether it is a safe abortion 
Aba, Y. A., Aba, G., Özkan, S.., \& Güzel, Y. (2016). Abortion policies around the world and in Turkey and its reflection on women's health. International Journal of Human Sciences, 13(1), 1651-1665. doi:10.14687/ijhs.v13i1.3580

should be determined in accordance with the technical and policy guidelines of WHO (Ganatra et all., 2014).

\section{Barriers when accessing abortion:}

- Restrictive laws

- Inadequacy of healthcare services

- High cost

- Labeling

- The conscientious refusal of healthcare providers

Also, mandatory waiting period, mandatory counseling, provision of misleading information, taking permission from the third parties and unnecessary medical tests delay abortion (WHO, 2012).

Every year, 46 million women get abortions around the world and 22 million of these are performed in unsafe environments. Each year, about 5 million women are hospitalized due to unsafe abortion. 47000 of these result in death and over 5 million women experience complications due to abortion. $13 \%$ of maternal deaths are reported to be linked to unsafe abortion. Out of every 10.000 unsafe abortions, 220 result in death. Despite the increase in contraceptive use, improvement in post-abortion care and reproductive rights, each year, 68.000 women around the world (36000 Africans) lose their lives due to unsafe abortion (Kalilani-Phiri et all., 2014). The most common complications are listed below (WHO, 2011; WHO, 2012):

- Incomplete abortion (failure in removal of intra-uterine tissue)

- Bleeding (severe bleeding)

- Peritonitis

- Sepsis

- Perforation of uterus

- Trauma of the cervix, vagina and uterus (genital organs)

- Damage in internal organs

- Infertility (intrauterine and / or tubal adhesions or damage).

- Death

Two thirds of all maternal deaths in the world occur in the African countries. As these morbidity and mortality rates are examined, it is seen that abortion is legally restricted in especially the African and Asian countries. In the developed areas of the world where willful miscarriage is not restricted, the ratio of maternal deaths due to miscarriage to all maternal deaths is around $1 \%$, whereas in countries that restrict/prohibit abortion, this ratio is seen to increase. The risk of mortality due to unsafe miscarriage is 1 in 250 for Asian women and 1 in 1900 for European women (Shaikh, Abbassi, Rizwan \& Abbasi, 2010). In Malawi, located in the African continent, 67300 willful miscarriages are reported to occur annually, $23.5 \%$ of maternal deaths in the country are caused by willful abortions and the most important reason for this is said to be unsafe abortion practices (Kalilani-Phiri et all., 2014).

In the USA, abortion is legally allowed with justification and the ratio of death due to abortion is 0.6 out of 100.000 , whereas this ratio is 30 out of 100.000 in Latin America, which has 
Aba, Y. A., Aba, G., Özkan, S.., \& Güzel, Y. (2016). Abortion policies around the world and in Turkey and its reflection on women's health. International Journal of Human Sciences, 13(1), 1651-1665. doi:10.14687/ijhs.v13i1.3580

rigid abortion laws; and 460 out of 100.000 in Sub-Saharan African countries (WHO, 2011). In addition to this, one fifth of all maternal deaths in Latin America are reported to be linked to complications of unsafe abortion. In Columbia, it is the third most common cause of maternal deaths (Animaw \& Bogale, 2014). Similarly, in Madhya Pradesh (population 51 million), one of biggest cities of India, only 3\% of the women can get abortion services from primary health care centers and 19\% of them can get it from public health centers (Banerjeea, Andersenb, Warvadekar \& Pathways, 2012).

In Pakistan, abortion is allowed only if pregnancy poses a threat to the mother's life. In the study of Shaikh et al. on mortality and morbidity rates due to unsafe abortion in Pakistan, the rate of urogenital system injuries was reported as $74 \%$ and $12 \%$ of the women were reported to lose their lives due to these complications, $6 \%$ were reported to have colostomies and $4 \%$ were reported to have total abdominal hysterectomies (Shaikh, Abbassi, Rizwan \& Abbasi, 2010).

The first study on abortion rate in Turkey was conducted by Dr. Zekai Tahir Burak, who examined the records of 5000 women who were referred to Ankara Maternity Hospital in 19531954. In this study, it was found that 30\% of these women's previous pregnancies resulted in miscarriage (spontaneous or willful); the maternal mortality rate in women who had miscarriages was four times the women who gave birth and that $27 \%$ of women who survived miscarriages were later infertile (Tezcan \& Ergöçmen, 2012). In Turkey, willful abortions cause 2\% of maternal deaths (26). Women's health indicators before and after the legalization of abortion in Turkey are presented in Table 3.

Table 3. The legalization of abortion Pre / Post Women's Health Indicators In Turkey (19832013)

\begin{tabular}{|l|l|l|}
\hline Indicator & 1983 & 2013 \\
\hline Induced Abortion rate (1000 women) & $0.76^{*}$ & $\mathbf{0 . 2 0 *}$ \\
\hline Effective use of family planning methods & $\% 20^{*}$ & $\% \mathbf{4 7 . 4 *}$ \\
\hline The maternal mortality rate (100.000) & $132^{*}$ & $15.9 * *$ \\
\hline Life Expectancy at Birth (Women) $* *$ & 57 & $79.2 * *$ \\
\hline
\end{tabular}

(*Hacettepe Üniversitesi Nüfus Etütleri Enstitüsü (2014), “2013 Türkiye Nüfus ve Sağllk Araştırması”. Hacettepe Üniversitesi Nüfus Etütleri Enstitüsü, T.C. Kalkınma Bakanlı̆̆1 ve TÜBİTAK, Ankara.)

(**Sağlık İstatistikleri Yıllığı, 2013)

\section{Conclusion}

In almost all developed countries for at least half a century, women who have unwanted pregnancies can reach healthy and safe pregnancy termination services. I those countries, even poor women don't have difficulty reaching safe service. For this reason, pregnancy termination through unsafe and dangerous methods is seen very rarely in those countries. However, women in undeveloped and developing countries are not so lucky. In most of these countries (56\%) women, because of laws forbidding safe miscarriages, have to refer to untrained people for help or try to end their pregnancy themselves. In many Middle and Southern America countries that apply the bans of the Catholic Church and in Africa, the situation is even more dire because of bans and poverty. Almost all of the women who want to terminate their pregnancies in those countries (97$100 \%$ ) have to resort to unsafe and dangerous methods (Sedgh, Singh, Henshaw \& Bankole, 2012; Shah, Åhman \& Ortayli, 2014). When regional distributions are checked, it can be seen that the areas with the strictest abortion policies are Oceania first and Africa, Latin America, and the 
Aba, Y. A., Aba, G., Özkan, S.., \& Güzel, Y. (2016). Abortion policies around the world and in Turkey and its reflection on women's health. International Journal of Human Sciences, 13(1), 1651-1665. doi:10.14687/ijhs.v13i1.3580

Caribbean after that. As of the year 2011 in 189 countries all around the world, except five countries(Chile, The Dominican Republic, El Salvador, Vatican, Malta, and Nicaragua), it is legally possible to terminate pregnancy for various reasons. Only these five countries don't allow legal miscarriages, even to save the mother's life.

In more than 80 percent of developed countries, legal abortion of pregnancy is provided because of economic, social, or physical health conditions, fetal development problems, sexual assault, incest, or the protection of the woman's life, and in $69 \%$ of those countries the service of abortion can be reached through preference without the need for showing any other reason. I developing countries, this rate is 62 and 41\%, respectively. Between 1996 and 2013 in 56 countries around the world (20 in Africa, 12 in Asia, 12 in Latin America and the Caribbean, 8 in Europe, and 4 in Oceania) the laws permitting abortion were expanded. Alongside this, laws permitting abortion were limited in 8 countries. These laws were limited in 3 countries in Latin America and the Caribbean, 2 countries in Africa, 2 countries in Asia, and 1 country in Oceania. Despite some countries, and regrettably Turkey, implementing applications that make it harder for women to reach safe abortion services, positive improvements in reaching the service can be seen globally.

Since the first population study performed in Turkey (1963), women with more resources are known to end their unwanted pregnancies no matter what the laws say. The first legal change on the subject of willing pregnancy termination was made in 1965, and legal pregnancy termination was allowed if there were medical reasons behind it. However, the number of women that could benefit from this possibility was seen to be very low. The legislation passed at 1983 recognized preferential pregnancy termination as a right for all women. According to the results of TNSA, the preferential miscarriage rates in Turkey have fallen from 0.76 (in 1000 women) in 1983 to 0.20 in 2013. Again, according o the results of this study, $61.9 \%$ of the women stated that they realized preferential abortion in the private sector. For this reason, how sufficiently preferential abortion records are kept is open to discussion.

Every year, 5 million women are hospitalized as a result of unsafe abortion. 47000 of those are known to end with death, and over 5 million women are known to experience abortion related complications. $13 \%$ of pregnancy related mother deaths are also known to be caused by unsafe abortion. 220 of every 100000 unsafe abortions end with death. In developed parts of the world where preferential miscarriages are not lmited, the rate of miscarriage related mother deaths among all maternal mortalities is approximately $1 \%$, and it is a point of concern that these rates are higher in countries where abortion is limited/banned.

According to the predictions of the Guttmacher Institute, the global treatment cost of complications caused by unsafe miscarriages is approximately 460-550 million USD. Treatment costs per case were calculated as 114 dollars in Africa and 130 dollars in Latin America (Singh et al., 2009). Although the fact that the direct and indirect costs of unsafe miscarriages are very high is known and the ways to decrease such miscarriages are known even better; countries still can't solve this problem at the root because of the differing views of politicians. Limiting laws have an effect of increasing unsafe miscarriages, not decreasing miscarriages, and the experiences of countries worldwide indicate as such.

Although abortion laws have been liberalized around the world in the last ten years, restrictions, limitations and prohibitions still continue in some countries; which lead women to have unsafe abortions. The serious consequences of performing abortions under unsafe conditions on women's health have been scientifically evidenced. Mortality and complications due to abortion can be prevented with sex education, effective contraceptive methods, safe and legal abortion and good post-abortion care. 
Aba, Y. A., Aba, G., Özkan, S.., \& Güzel, Y. (2016). Abortion policies around the world and in Turkey and its reflection on women's health. International Journal of Human Sciences, 13(1), 1651-1665. doi:10.14687/ijhs.v13i1.3580

\section{References}

Abortion Clinics in Europe, Legal situations in Europe, http://www.abortion-clinics.eu/ 15.04.2015

Animaw W., Bogale B. Abortion In University And College Female Students Of Arba Minch Town, Ethiopia, 2011. Sexual \& Reproductive Healthcare 2014; (5): 17-22.

Banerjeea SK., Andersenb KL., Warvadekar J. Pathways And Consequences Of Unsafe Abortion: A Comparison Among Women With Complications After Induced And Spontaneous Abortions in Madhya Pradesh, India. International Journal of Gynecology and Obstetrics 2012;118(2): 113-120.

Bozkurt B. Kürtaj Yasalarının Nüfus Politikalarıyla İlişkisi: 1960'lardan Daysümüze Türkiye. Yıldız Teknik Üniversitesi İktisadi Ve İdari Bilimler Fakültesi Siyaset Bilimi Ve Uluslararası İlişkiler Bölümü. Lisans Bitirme Tezi. 2013

Darney BG, Simancas-Mendoza W, Edelmana AB., Guerra-Palacioc C., Tolosaa JE., Rodriguez MI. Post-Abortion And Induced Abortion Services in Two Public Hospitals in Colombia. Contraception 2014; (90):36-41.

Fiala C. Are The Laws And Practices Patient Centred? Lazdane G, Lazarus JV, (edts). Abortion In Europe, Entre Nous, Reproductive Health and Research Programme, WHO, Switzerland, 2005; 59:23-25.

Ganatra B, Tunçalp Ö, Johnston HB, Johnson BR, Gülmezoglua AM, Temmermana M, From Concept To Measurement: Operationalizing WHO's Definition Of Unsafe Abortion, Department of Reproductive Health and Research, World Health Organization, Bull World Health Organ 2014; 92:155.

Hacettepe Üniversitesi Nüfus Etütleri Enstitüsü. 2013 Türkiye Nüfus ve Sağllk Araşttrması. Hacettepe Üniversitesi Nüfus Etütleri Enstitüsü, T.C. Kalkınma Bakanlığı ve TÜBİTAK, Ankara. 2014.

Jones RE, Lopez KH, (edts). Human Reproductive Biology, Elsevier,London, UK 4. Edition, 2013. p. 272

Kaleci AO, Mete Ç, Ünsal C, Yıldırım AK. 1983 Tarihli "Rahim Tahliyesi ve Sterilizasyon Hizmetlerinin Yürütülmesi ve Denetlenmesine İlişkin Tüzük"ün Hazırlanmasındaki Tarihsel Süreç. Başkent Üniversitesi, Tıp Fakültesi XV. Öğrenci Sempozyumu, Bildiri Kitabi, 2013, Ankara.

Kalilani-Phiri L., Gebreselassie H., LevandowskiBA, Kuchingale E., Kachale F., Kangaude G. The Severity Of Abortion Complications in Malawi. International Journal of Gynecology and Obstetrics, 2014; 128(2): 160-164.

Kauffman C. State-Sanctioned Femicide: How Criminalizing Abortion Puts Women's Lives at Risk. http://dejusticiablog.com/2015/02/10/state-sponsored-femicide-how-criminalizingabortion-puts-womens-lives-at-risk/ 19.06.2015

Kubilay Ç. İslami Muhafazakâr Kadın Yazarların Perspektifinden Kürtaj Tartışması: Eleştirel Bir Değerlendirme, Alternatif Politika, 2014;6(3): 387-421.

Levels M, Sluiter R, Need A. A Review Of Abortion Laws in Western-European Countries. A Cross-National Comparison Of Legal Developments Between 1960 and 2010. Health Policy. 2014;(118): 95-104.

Nüfus Planlaması Hakkında Kanun. T.C. Resmi Gazete. 01.04.1965. Say1:557

Nüfus Planlaması Hakkında Kanun. T.C. Resmi Gazete. 24.05.1983. Sayı: 2827

Rahman A, Katzive L, Henshaw SK, A Global Review of Laws on Induced Abortion from 1985-1997. International Family Planning Perspectives 1998; 24(2):56-64

Sedgh G, Singh S, Henshaw SK, Bankole A. Induced Abortion: Incidence And Trends Worldwide From 1995 To 2008. Lancet 2012; 379(9816):625-632 . 

on women's health. International Journal of Human Sciences, 13(1), 1651-1665. doi:10.14687/ijhs.v13i1.3580

Shah IA, Åhman E, Ortayli N. Access To Safe Abortion: Progress And Challenges Since The 1994 International Conference on Population and Development (ICPD). Contraception. 2014;90(6): 39-48.

Shaikh Z., Abbassi RM., Rizwan N., Abbasi S. Morbidity And Mortality Due to Unsafe Abortion İn Pakistan. International Journal of Gynecology and Obstetrics 2010; (110): 47-49.

Tezcan S. , Ergöçmen Akadalı B. Türkiye'de İsteyerek Düşükler. Türkiye Halk Sağlığı Dergisi 2012;10(1): 36-42.

Türk Jinekoloji ve Obstetrik Derneği. Kürtaj ve Kadın Sağlığı. 2013. http://www.tjod.org/turkjinekoloji-ve-obstetrik-dernegi-tjod-kurtaj-raporu/

T.C. Sağlık Bakanlığı. Sağlık İstatistikleri Yıllığı 2013. Sentez Matbaacılık ve Yayıncilık. Ankara. s:22.

United Nations (a). Department of Economic and Social Affairs, Population Division. Abortion Policies And Reproductive Health Around The World, 2014.

United Nations (b). Department of Economic and Social Affairs, Population Division. Population Facts, August, 2014. No:2014/1: 1-4.

World Health Organization, Unsafe Abortion: Global and Regional Estimates of the Incidence of Unsafe Abortion and Associated Mortality in 2008, sixth ed., Geneva: WHO, 2011.

World Health Organization, Safe Abortion: Technical And Policy Guidance For Health Systems, Second Edition, Switzerland, WHO, 2012, p.17-26 